\title{
Relationship between Selected School Determinants and Examination Cheating tendencies among Kenyan Secondary School Students
}

\author{
John Timon Odhiambo Owenga
}

PhD in Educational Psychology

Pamela A. Raburu

$P h D$ in Educational Psychology

Peter J. O. Aloka

PhD in Educational Psychology

Doi: $10.2478 / \mathrm{mjss}-2018-0066$

\begin{abstract}
The present study investigated the relationship between selected school determinants and examination cheating among Kenyan secondary school students. This study used a Sequential Explanatory design in Mixed Methods approach. The target population was 51,900 students in Kisumu County within 153 public secondary schools categorized as 2 National secondary schools, 21 extra county schools, and 130 county and sub-county schools with a total student population of 51,900 in Kisumu County. A simple random sampling technique was used to determine sample size which comprised of 380 respondents since the study was confined within specific ecological boundary which was public secondary schools. Data collection instruments included questionnaires, for general data collection from the respondents and in-depth interview schedules for one to one interview of respondents. The finding of the study shows that there was statistically significant, though weak, positive correlation $(r=.211, n=360, p<.05)$ between school determinants and overall perceived level of exams cheating. The model shows that school determinants accounted for $4.5 \%$ (Coefficient $R^{2}=.045$ ) of the variation in exams cheating among the students in secondary schools. The Ministry of Education should create ethical academy that would enhance a systems approach to understand misconduct and to empower change in higher education through ethical examinations. This is because the study reported that examination cheating is mainly determined by teachers with low ethical standards.
\end{abstract}

Keywords: school determinants; examination cheating tendencies; teachers; peer; Secondary School

\section{Introduction}

Cheating on examinations has become a monster seeking to consume the entire Nigerian academic community (Afokasade, Airate \& Suleiman, 2014). Bisong Akpama and Edet (2009) added that examination malpractices in African countries need a critical survey due to its place in academic standards. The study affirms that there has been remarkable cheating tendency in examination among secondary schools students in Africa while Matamande, Mandimika, Tanderera and Nyikahadzoi (2010) made in Zimbabwe affirmed that students in schools are a making of examination systems represented by teachers and examination managers or handlers. This is an indicator enough that apart from students, teachers and schools at large act as agents for examination cheating syndromes while Osim and Ndifon, (2013) reported that the schools which 
excelled more in National Advanced level examinations were the usual giant schools yet abnormality was observed in their grading, an indication of examination malpractice in Uganda. According to Odia Ochuko (2011), in Nigeria, examination cheating in Africa thrives on the basis of survival of students from being caught. This act encourages students to cheat more and more as long as they are not caught or discovered. Kunle Awosiyan and Clement Idoko (2012) in Ghana revealed that examination cheating is fraudulent and held at a high esteem by the students first, than the teachers. The parents are seen as blind followers of both the teacher and the student who are seen to be holding the password for academic malpractice. Nurami (2011) also pointed out that the individuals find themselves entangled in examination cheating tendencies which are detrimental to ethical or sound educational system.

Paul, Grimes and Jon (2006) revealed that a substantial number of students admitted to have cheated in examinations and also to have assisted others to cheat in examinations. This study also revealed that the numbers of students who admitted to have cheated or assisted other students to cheat were higher in transitional economies such as Belarus, Lithuania and Croatia than United States of America (USA). McCabe and Trevino (2012) also affirmed that students who cheat at personal level always lack principles and hence can't think or act independently but are always influenced by others who are above them or their contemporaries. Paul, Grimes and Jon (2006) also revealed that all students reported to have cheated or assisted one to cheat. However, organizing campaigns, workshops and orientations, together with engaging the students in knowledge from the lessons rather than scores, grades or certificates are the best strategies in attempting to eradicate cheating in schools (Thonoghdeth and Vongdeuan, 2013).

According to Nyamwange, Ondima and Onderi (2013) examinations are also used for placing students in various institutions and jobs and provide feedback in the teaching and learning processes and curriculum delivery in general. In Kenya, examinations cheating is mainly encouraged by teachers and executed by students in secondary schools, (Ngugu,2011).According to Ong'ong'a and Akaranga (2013), examination cheating in Kenya is not a strange occurrence and reports of examination malpractices have always presented clearly from 2004 to 2008 with several examination results canceled or withheld. Synovate, (2009), reported that most students in the 8-44 feel that most subjects taught are irrelevant and there is too much emphasis on examination to actual acquisition of relevant knowledge and skill for the industry and also indicated that many students opted to use unethical means to acquire better examination results.

The study was guided by the Ecological Systems Theory by Uri Bronfenbrenner.Ecological Systems Perspective Theory (ESPT) is sometimes known as Human ecology Theory (HET),(Bronfenbrenner, 1979). Ecological systems theory explains that the different environments people experience throughout their lives may influence their behaviour in varying degrees. The theory informs the study that a student may be influenced by his or her environment to get involved in practices such as examination cheating tendencies.Schools according to McCabe \& Pavella, (2006), provide a very important environment for examination cheating which consists of the teachers, principals, subordinate staff, students and peers. According to Kohn (2007), while students are involved in personal cheating tendencies, it's imperative to note that they also play an important role as school determinants in cheating tendencies.Taradi, Taradi and Dogas, (2011) stressed that examination cheating is a making of the teachers hence uses with assumption that would improve the students self-efficacy as they move ahead.Sonja and Panu (2012) study in Indian Public schools about the preference and skills of teachers in schools revealed that teachers are responsible for the cheating in schools since they assist their students in the subjects during exams.

Andrabi, Das, Khwaju and Zajonc, (2011) also revealed that the teachers role in examination cheating was so acute presenting as:- gross inadequacy of qualified teachers in school, a factor that makes teachers the best solution to exam cheating which they have the powers to deal with fully.Henning, Ram, Malpas, Shulruf, Kelly and Hawken, (2013) study out in New Zealand College emphasized that those who promote examination irregularity are principals and head teachers who are expected to be the lead in moral inculcation to stamp out exam irregularities.Burdzicka, (2008), study in Poland suggested that cheating in schools is so complex that only professional and competent teachers can carry it out since the chain of dishonesty is so long, embracing all the 
stakeholders, which include the teachers, students and even examiners.According to a study in New York by Clark-Carter (2009), the validity and reliability of examinations or test are mainly determined by teachers. The teachers may make the examinations test what they are meant to test and give the correct measurement of individual examinees.Ashworth, Bennister and Thome, (2006), found out that the teachers play very active role in propagating presenting them as bad role models to their own students who believe in all said and done by teachers. The study was supported by Archin (2009) who stated that, the authenticity and reliability of examination or test are mainly influenced by teachers.In a study carried out in Belarus; Croatia, Kyrgyzstan, Lithuania, Russia, Ukraine and USA students on determinants of cheating by high school students -Grimes and Razek, (2006) revealed that Significant determinant of cheating was mainly influence of teachers and the peers in schools.

There has been a significant increase in examination cheating tendencies among students of public secondary schools in Kenya, especially Kisumu County. The act of examination cheating has been increasing steadily despite the studies carried out previously. According to KNEC (2016) report, the increase in number of cheats whose results were canceled was so alarming to warrant close attention, see table 1. Examination cheating is a vice that has bedeviled public secondary schools in Kisumu County since 2011 when the country had the highest number of cheating cases. For instance, in the year 2013, a total of 239 students in Kisumu County out of 3353 nationally, making $7.2 \%$ of all 47 counties had their results canceled due to exam cheating,(KNEC, 2016) which is a very significant phenomenon that warrants an empirical study. The act is likely to be caused by those students whose intention is to have unfair advantage over the rest of the students due to competitiveness in the high stake examinations. Despite the prevalence in examination cheating tendencies in both Kenya and Kisumu County, little has been done to curb this act. The causes therefore need to be unearthed and solution be prescribed to stamp out the possible causes of examination cheating tendencies given that examination cheating may lead to production of half baked graduates from the universities, harmful professionals in job markets and bad reputation to the learning institutions where the act is practiced according to Ochuko (2006). The present study investigated the relationship between selected school determinants and examination cheating among Kenyan secondary school students.

\section{Research Methodology}

This study used a Sequential Explanatory design in Mixed Methods approach. Sequential explanatory design involves collection and analysis of quantitative data followed by collection and analysis of qualitative data leading to authentic study findings (Onueghbuzie \& Mayo 2013). The target population was 51,900 students in Kisumu County within 153 public secondary schools categorized as 2 National secondary schools, 21 extra county schools, and 130 county and subcounty schools with a total student population of 51,900 in Kisumu County (MOEST 2014). A simple random sampling technique was used to determine sample size which comprised of 380 respondents. Data collection instruments included questionnaires, for general data collection from the respondents and in-depth interview schedules for one to one interview of respondents. Quantitative data was analyzed by descriptive statistics and inferential statistics. According to Creswell (2014) study, qualitative analysis is an integral part of mixed methods that gives the respondents opportunity to express themselves freely during face to face interviews.

\section{Findings \& Discussion}

To investigate whether there was any statistical relationship between school determinants and exams cheating, the null hypothesis was tested. To do this, a Pearson Product Moment Correlation Coefficient was computed, with overall scores from the two school determinants (peer influence and teacher involvement) put together as the independent variables, while the level of exams cheating as the dependent variable. Preliminary analyses were performed to ensure no violation of the assumptions of normality. Table 1 shows the correlation analysis results in SPSS output. 
Table 1: Correlations between Exams Cheating and School Determinants

\begin{tabular}{llcc}
\hline & & Exams Cheating & School Determinants \\
\hline \multirow{3}{*}{ Exams Cheating } & Pearson Correlation & 1 & $.211^{\prime \prime}$ \\
& Sig. (2-tailed) & & .000 \\
& $\mathrm{~N}$ & 360 & 360 \\
\multirow{5}{*}{ School Determinants } & Pearson Correlation & $.211^{* *}$ & 1 \\
& Sig. (2-tailed) & .000 & 360 \\
& $\mathrm{~N}$ & 360 & \\
\hline \multirow{*}{**}{ Corredation }
\end{tabular}

${ }^{* *}$. Correlation is significant at the 0.01 level (2-tailed).

The finding of the study shows that there was statistically significant, though weak, positive correlation $(r=.211, n=360, p<.05)$ between school determinants and overall perceived level of exams cheating. Given that the relationship was statistically significant, the hypothesis that, "there is no statistical significant relationship between school determinants and exams cheating" was rejected. It was therefore concluded that exams cheating significantly correlated to school factors, mainly teachers and peers.

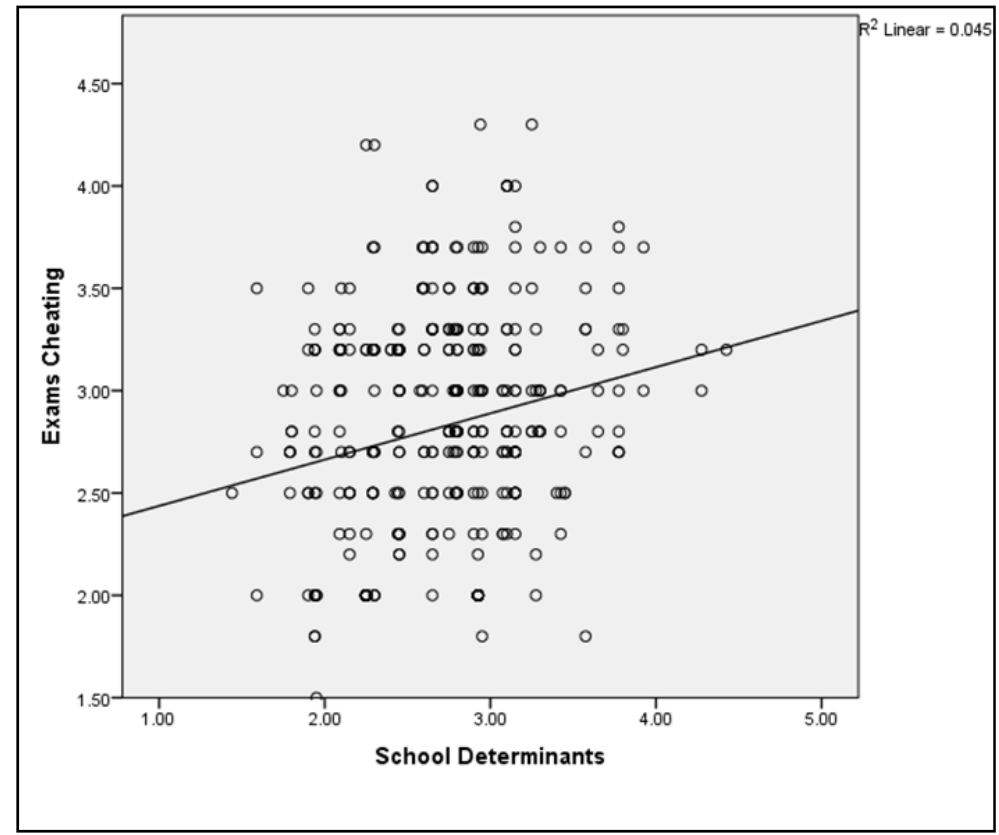

Figure. Relationship between School Determinants and Exams Cheating

The scatter plot indicates that there was some evidence of a positive correlation between two variables as indicated by the scatter plots behaviour on the trend line. This is because the coordinate points cluster near the line of best fit or trend and were scattered around it forming almost a visible pattern; implying that the two data sets were agreeing. However, to estimate the level of influence of school determinants on exams cheating, a coefficient of determination was computed using regression analysis and the results were as shown in Table 2. 
Table 2: Regression Analysis model of the relationship between School Determinants and Examinations Cheating

\begin{tabular}{ccccc}
\hline Model & $\mathrm{R}$ & $\mathrm{R}$ Square & Adjusted R Square & Std. Error of the Estimate \\
\hline 1 & $.211^{\mathrm{a}}$ & .045 & .042 & .54092 \\
\hline
\end{tabular}

a. Predictors: (Constant), School Determinants

The model shows that school determinants accounted for $4.5 \%$ (Coefficient $R^{2}=.045$ ) of the variation in exams cheating among the students in secondary schools. However, to determine whether school determinants were a significant predictor of examinations cheating, Analysis of Variance (ANOVA) was computed as Table 3.

Table 3: ANOVA -Relationship between School Determinants and Exams Cheating

\begin{tabular}{lccccc}
\hline Model & Sum of Squares & Df & Mean Square & F & Sig. \\
\hline Regression & 4.882 & 1 & 4.882 & 16.687 & $.000^{b}$ \\
1 Residual & 104.747 & 358 & .293 & & \\
Total & 109.630 & 359 & & & \\
\hline
\end{tabular}

a. Dependent Variable: Exams Cheating

b. Predictors: (Constant), School Determinants

From Table 3, it is evident that school determinant was a significant predicator of perceived level of exams cheating $[F(1,358)=16.687, p<.05)$. This further confirms that use of school determinant significantly influence exams cheating among secondary school students. In conclusion, given the fact that both the school determinants were all significantly positively correlated with exams cheating, suffice we rejected the null hypothesis and consequently upheld the assertion that there is statistical significant relationship between school environment variables and examination cheating among secondary school students in Kisumu County.

Qualitative findings also showed that teacher involvement in examination cheating is observable mainly manipulation of the students, examination management and syllabus coverage. The teachers being key components of school environment are seen as the ones to give direction to students pertaining examination cheating. The respondents observed that teachers also prompt them to cheat in exams a fact that was supported by Ugwu, (2008) that teachers have the knowledge appreory to dealing with exams cheating, when they recent them cheating takes place.Teachers influence was rated high with several respondents alluding to it as a school determinant of examination cheating tendencies. This is quite significant since at least five respondents had a feeling that cheating is influenced by teachers who prompt students to cheat. This was also shown by the verbatim expressions of the respondents as the one here below:-

Subject teachers are responsible for cheating so that their subjects may rank high as a means to get favour from the school and parents (County Education Officer. 2)

The statement by Education Officer 2 indicates that teachers are also determinants of examination cheating in schools. The respondent states categorically that subject teachers are the ones who influence or determine cheating in schools since there are incentives given to the teachers of the subjects which perform better. This fact is accredited by a study carried out by Chudzika, Lupinai, Borter, and Hapon (2013) that students will cheat when they are prompted by their teachers who prompts them to cheat in order to give accreditation to their subjects. The study further stated that incentives in schools are what make teachers to assist their teachers who prompt them to cheat in order to give accreditation to their subjects. The study further stated that incentives in schools are what make teachers to assist their students to cheat in examinations.

My teachers help us, the candidates in our school with papers which they revise prior to the main exams. That has always made us to think that they get exams irregularly to help us cheat (Student. 1). 
One of our teachers is known for helping the students during practical exams by showing them what to do... I think this one is cheating, I don't know.......but you can decide.... (Student.2).

Student 1 and Student 2 informed this study that they have observed teachers assisting their students to cheat in schools. The expressions are an indicator that the students may not want to cheat but they do so because their teachers are influencing them to do so. This one shows that teachers are also school determinants to exam cheating. This fact was supported by Achin and Jones, (2009) who stated that teachers experience and competence in handing examination classes has been lacking in schools and colleges. The findings showed that college students where the study was carried had teachers who can only teach but not prepare students to undertake specific tasks such as examinations, a fact that was confirmed by Glick (2010) that incompetent teachers cannot produce competent students and will always mislead them that exams is so difficult that one can't pass without cheating.

"I don't like cheating, but when I think of my teachers' statement that I recall what they have taught us during exams, I find myself panicking and so resort to unethical means of passing exams such as, cheating" (Student4).

The respondent above confides to the study that, there are things or answers that their teachers have prepared and so prompts them to recall and use them during examination. When one tells a person to recall something during examination, it is always assumed that one required to recall had been exposed to the exam question prior to the exam date and the answers are prepared in advance which they are required to recall and use during exams. (Kujala, Lamsa and Penttila, 2011) system and may just reproduce the teacher (Nwankwo, 2011). Another student reported that:

\begin{abstract}
"I don't like cheating, but when I think of my teachers' statement that I recall what he has taught us during exams, I find myself panicking and so resort to unethical means of passing exams such as, cheating" (Student 4).
\end{abstract}

When students get 'live' exams or leakage, it's the teachers who help formulate the marking scheme it's also some of the teachers who look for the leaked exams and bring to school, which the principals also approve of. (Student 3)

The respondents, Student 4 and 3 confided to the study that, there are things or answers that their teachers have prepared and so prompts them to recall and use them during examination. When one tells a person to recall something during examination, it is always assumed that one required to recall had been exposed to the exam question prior to the exam date and the answers are prepared in advance which they are required to recall and use during exams. (Kujala, Lamsa and Penttila system and may just reproduce the teacher (Nwankwo, 2011). This one shows that cheating is also influenced by teachers at personal level.

The qualitative findings of the study also established that head teachers have much influence in determining the level of examination cheating in secondary schools in Kenya as herein stated: Head teachers' influence refers to the way head teachers or principals of secondary schools determine examination cheating among the students. This was also found out by thematic analysis from the interviews of various respondents which further proves that many respondents interviewed, indicated that principals of their schools are responsible for cheating which is a quite a significant response for this study. This was discussed by various respondents as exemplified here below:

"Cheating is done by students, but with the approval of school principals, who double as instructors as well as the managers of the institutions. As instructors, they help cheating for good grades in their schools and monitory gain. As managers and supervisors they do so to maintain status quo."(Teacher.2)

"Most leakages are encouraged by the principals of the schools in collaboration with examination council and parents, it's the teachers who help formulate the marking scheme and it's also some of the teachers who look for the leaked exams and bring to school, which the principals also approve of."(Student.1) 
"It's true that some principals of our schools encourage cheating in their schools in order to get better grade, and good names which leaves a lot to be desired?"(Head teacher. 3)

Teacher2, Student 1 and Head teacher 3 show that examination cheating is to a larger extent influenced by school administrations in secondary schools. The principals of schools are also seen to determine cheating since they are the perceived beneficiaries of examination cheating. This is true according to Ugwu (2008) who outlined that the principals and examiners at times collude to come up with examinations malpractice which is a manipulative method that has a long chain and history and also affirmed that school administrators and examination cheating was cited as a need by the school administration to get better name and praise among other schools within their regions.

Inadequate preparation or adequate preparation has also featured as a determinant to examination cheating within school level. The perception in this factor is seen as a resultant of students preparing and teachers aiding the preparedness. The prepared student is perceived to be ready to handle examination with little difficulties compared to non-prepared one. The preparation in this essence is by both teachers and students are presented by the following:-

"When am not prepared for exams, I will cheat. The teachers have the responsibilities of assisting us well enough in order to be prepared for exams." Student 5" I don't blame teachers on lack of preparation, but my fellow students since, they know what is required and that is why they cheat." (Student 3)

"Teachers don't help our children well to prepare for exams. If they do then there is less cheating in schools than what we can see now. (Parent 1)

"Some teachers are not prepared for lessons they teach students well for exams. A well prepared student will do better in exams without cheating." (County Education Officer. 2)

"We prepare students well, but students also do have a responsibility to prepare for exams. The teachers should get involved by $20 \%$ delivery while remains for the students and other external factors."(Teacher. 2)

The responses by Student 3, Parent 1, CEO 2 and Teacher give signal that, cheating in examination has a direct connection with preparation for examinations through proper teaching and coverage of syllabus by both teachers and students. Lack of preparedness is seen as detrimental to passing exams and hence a determinant of examination cheating at school level as well as personal levels. Early syllabus coverage emerged strongly as a strategy to controlling examination cheating in schools because inadequate preparation was cited as a determinant of exam cheating. This was supported by a significant majority who stated that the schools need to ensure early syllabus coverage. This one is making sure that teachers ensure good syllabus coverage to help students prepare early for examinations to avoid cheating. The respondents further contributed as presented below:-

Cheating is encouraged by those teachers and students who haven't completed the syllabus. Syllabus coverage improves self-efficacy and can help in reducing examination cheating." (Head teacher. 2)

Coverage of syllabus is a must and any school or teacher that fails to observe this is actually paving way for failure or examination cheating, hence this must be the target of every subject teacher. (Teacher. 1)

The response by Head teacher 2 and Teacher 1 shows that examination cheating is also caused by laziness and poor syllabus coverage by both the students and teachers. The findings were supported by Davis, Drinana, and Callant (2012) study that, cheating is mainly encouraged in schools by teachers and students due to laziness. The teachers through the approval of the principal teachers and Heads of departments give a clean bill of health to cheating to cover up for incomplete syllabus and laziness of those affected which in real essence is a corrupt and unethical 
means of survival.

Most of our schools are not interested in syllabus coverage; instead they are busy involving students in doing exams every time. Some teachers are so hasty in covering the syllabus that they leave very important things that can help the students in exams. The students don't have any alternative but to cheat in exams. (Head teacher.1).

A good syllabus coverage facilitated by teachers will lead to a reduction of examination cheating tendencies among students since teachers have an easy means of preparing students for examinations. (Teacher. 2)

Yes, syllabus coverage in quite important. The teachers sometimes leave the work for us to do so as to help them cover the syllabus. When we find it difficult to do this, we look for short cuts to passing exams..... (Student. 4).

The expressions by Head teacher 1, Teacher 2 and Student 4 are indicators that syllabus coverage is a very important aspect to be looked at as far as examination cheating is concerned. When syllabus is well covered or adequately covered by both the teacher and the student, the chances for cheating is very much reduced and the learners develops self-satisfaction and esteem, (Ukpeph and Ndifon (2012). The findings were given credence by a study carried out by Nurami (2011) who attributed examination cheating to laziness and indolence of both teachers and students. In addition, Ugwu (2008) study in Nigeria also affirmed that school administrators and examination cheating was cited as a need by the school administration to get better name and praise among other schools within their regions. The teachers can make examinations to test what they are meant to test and give the correct measurement of each and every student. This information was supported by the various respondents as here in below:

"Cheating is done by students, but in conjunction with other players such as teachers, who double as instructors as well as the supervisors and invigilators. As instructors, they help cheating for good grades in their subjects and monitory gain. As invigilators and supervisors they do so for their own personal reasons."(County Education Officer 1)

"When am not prepared for exams, I will cheat. The teachers have the responsibilities of assisting us well enough in order to be prepared for exams."(Student 3)

"Teacher involvement in cheating is quite significant, since it's the teachers who receive the examination from students and help them in revision or finding the answers. The teachers also participate by talking to the invigilators to be lenient when it comes to exam." (Parent 1)

The responses by Student 3 and Parent 1 are indications that examination cheating in schools is influenced by teachers during both instruction and examination invigilation or supervision. The above observation by the respondents is an indicator that there is teacher involvement as a determinant to examination cheating in schools. These can also be traced from studies made by Paul and Jon (2006) in USA, Russia and Ukraine which found out that cheating is a student affair whether at home or in school, whether college or in the university, yet the teachers support cannot be ruled out. The most rampant hands in cheating according to Paul and Jon (2006) are the subject teachers who are the technocrats in the very field in question. Moreover, Osim and Ndifon (2013) in Nigeria reiterate that the teachers determine to a larger extent the delivery content but most of them are not convinced that their students have the capacity or self-efficacy to handle exams, so they resort to assisting them to cheat in exams.

\section{Conclusion \& Recommendation}

School determinants of examinations cheating tendencies also emerged where several observations showed that teachers influence was the major factor of examination cheating giving leeway to poor syllabus coverage and poor examinations management. Several respondents also cited peer influence as a determinant of examination cheating within school level. It was finally 
concluded that all the factors mentioned were influenced by teachers and head teachers of the various schools. The study concluded that teachers and peer were perceived as the main determinants of examination cheating tendencies in secondary schools. However it was also agreed upon that poor syllabus coverage and examination management also contribute to examination cheating within schools.Ministry of Education to include moral education in the school syllabus to ensure higher moral standards among students to help in overcoming examination irregularity. This may improve self efficacy and self esteem among students this is because the study reported that students with low self esteem cheat more in exams than those with higher self esteem.

\section{References}

Afokasade, A. \& Suleiman (2014) Determinants of Nigerian students. Disposition to cheating. The Perpetrators' perspective. The international Journal of Learning in Higher Education, Vol 20 issue 4, 2014, PP31 - 37.

Ashworth, P., Bernnister. P \& Thome. P. (2006), University Students Perception of Cheating and Plagiarism in Academic assessment.Journal of studies-Higher Education. 22(2): 187-203..

Azuka, N.G. Alutu (2006).Secondary Schools Students' Perception of and Examination Ethics", in Journal of Humanities and Ecology,20(4),pp. 295-3.

Bandura, A. (1986). Self - efficacy: The exercise of control. New York: W.H. Freeman.

Bisong, NN (2009). Cheating tendencies in Examination among secondary schools in

Nigeria: A case study of schools in the Odulepani local Government Area. Journals.Sage pub.com/da/abs/10.2304/pf/c.2009.7.4.410.

Cizek.G.I (2003), Detecting and preventing classroom cheating: Promoting integrity in assessment. California: Corwin.

Christine H.L Graven J, Gary M.R, Davis, D, Murray, M.A \& Rydall A.C (2015): empirical study on relationship between self efficacy and adherence Department of psychology, college wing 2. 306, Toronto University, press, Toronto, Ontario (Canada).

Chudzika\&Czupala (2014) Psychological and moral determinants in accepting cheating in Poland..www.p.Jap.psychologia.uni.wroc.pi-/..../Poland.Europe institute of psychology, university of sitesia, grasynkiego. 53, 40-126 Katowixer

Cornelius, Ukpeph \& Ndifon, R A. (2012) Factors that influence examination malpractice and academic performance in primary science among primary six pupils in Gross river state, Nigeria Journal of Education and practice.Vol 3, No. 9, 2012.

Cresswell, J.W, (2014) Research Design:Qualitative; Quantitative and Mixed method approaches Thousand Oaks, C.A Sage.

Davis, F.S Drinan, F.P \& Gallant, B.T (2012) Cheating in school. What we know and what we can do. Willey Blackwell. John Willey Ltd.

Evans, P., \& Wolf.(2005). Collaboration rules.Harvard Business Review July-Aug: 1-10.

Finn, K. V., \&Frone, M. R. (2004).Academic performance and cheating: Moderating role of school identification and self-efficacy.Journal of Educational Research.97(3), 115-122.

Idaka, I.E Idika, D.O \& Egbona, A.E (2011) An analytic model of psychosocial variables as determinants of cheating tendency among secondary school. African Journal of education, volume 1 Number 2 (2011), pp 68-75.

Kagendo, E Njue G.M, Muthaa, \&Muriungi, P.K (2014). Effectiveness of Examination handling and distribution procedure and malpractice in secondary schools in Eastern province, Kenya. University of Nairobi Press. Nairobi, Kenya.

Kohn, A. (2007) "Who's cheating whom?" Journal of Research, Phi Delta Tappan 89, 88-97.

Lambert, B., and Foss, K (2005). Guiding students from cheating and plagiarism to Honesty and integrity: Strategies for change. Engle Leland, B. (2002). Plagiarism and the Web.Macomn, IL: Western Illinois University. Available at: http: // www.wiu.edu/users/mfbh/wiu/plagiarism.htm.

Mahenshwari, J.A. (2011). "Monitoring Works: getting Teachers toCome to School:" Bureau for Research and Economic Analysis of Development (BREAD) Working Paper103.

Matamande; Mandimika. W, Tenderera. E \& Nyikahadzoi, 2 (2010) Exploring management strategies to reduce cheating in written exams.A case study of Midland State University, Zimbabwe.

McCabe.D.L, Trevino. L.K. \& Butterfield, K.D (2012) Cheating in college: why students do it and what educators can do about it.John Hopkins University Press. The United States of America.

MOEST, (2014).Use of mobile phones during examinations.

MOE/CON/FIII/41/5.Nairobi: MOE 
Muralidharan, Karthik, and Sundaraman, V (2008). "Contract Teachers: Experimental Evidence from India."http://econ.ucsd.edu/-kamurali/contract\%20teachers.pdf

Ngugu, J.K (2011). Factors influencing examination malpractices by students in Kenya certificate of secondary schools examination in Kitui West,Kenya. URI: http://expository:uonbi.ac.ke:8080/handle/1-9/4183-2011.

Nuraimi, A (2011): Causes, effects and solutions of exam malpractice in Lower state Nigeria, Journal of social science volume 40: number 11 (2011):238)

Nwankwo, P (2011). A Survey of Examination Malpractice among Secondary School Students- Causes, effects and Solutions. GRIN Verlag.

Nyamwange, C, Ondima, P \& Onderi: P. O (2013) Factors Influencing Examination Cheating among secondary school students, Kisii County: Elixir Psychology Journal 56 (2013) PP 13519-13524.

Ochuko, O. (2011). 'Ethical Dimension in Examination Malpractice', in Nigeria Journal of Education, Health and Technology Research (NJEHETR), Vol. 1 No. 1.

Olaleye, P.O. (2006) Academic performance and cheating intermediate; Journal of research in education, Vol. 5, No. 1.PP 77-94.

Ogodulunwa, CA (2011). The attitude of students to cheating in Examination in Nigeria. Journal of Education. Volume 10, number 7, PP 384-398.

Ong'ong'a, J. J.\& Akaranga, S.I. (2013) The Phenomenon of examination Malpractice: An example of Nairobi and Kenyatta Universities. Journal of Education and Practice Vol. 4.19: pp 1- 40.

Paul, W. Grimes \&. Rezele ,P. (2006) The determinants of cheating by High school students: A comparative study of Academic Dishonesty in the Transitional Economies. International Review of Economic of Education, Vol 4 issue 2 P.P 23-45.

Punch.K. (2005).Introduction to Social Research: Qualitative and Quantitative approaches. London Sage.

Raburu, P.A (2015). Motivation of women academics and balancing family and Career. Journal of Educational and Research Vol.5. NO.1:359-370.

Republic of Kenya (2010) Education statistics and indicators fact sheet. Nairobi; Ministry of Education

Sonja \& Panu (2012).Academic Misconduct in higher education: Durham University Press.Durham $\mathrm{E}$ Thesis.online.http://ethesis.dur.ac.uk/2546/.

Stumber,T.S (2011) Gender factors determining examination irregularities in USA. Journal of Educational and Research Vol.5. NO.1:247 -308.

Thonoghdeth, N.\& Vongdeuan O. (2014) student factors influencing cheating in examinations. A case study of Loas in Dongkok.china.

Uti, A (2012) Relationship between parenting styles and students academic achievement in secondary schools in Ethiopia.Journal of Education and Research vol.4 pp 243-271. 